\title{
GAMBARAN MEDICATION ERROR (ME) PADA PENGOBATAN GASTRITIS PASIEN RAWAT INAP KLINIK PRATAMA AL MADINAH DI KABUPATEN BREBES
}

\author{
Anggy Rima Putri, M.Farm., Apt ${ }^{1}$, MeliyanaPerwita Sari, M.Farm., Apt ${ }^{2}$ \\ Email penulis :2018anggy@ gmail.com \\ ${ }^{1}$ Politeknik Harapan Bersama Jalan Mataram No 9 Kota Tegal 52142, Indonesia Telp ( 0283 ) 352000
}

\begin{abstract}
Abstrak
Gambaran dan persentase kejadian medication error yang terjadi pada pasien gastritis rawat inap di klinik pratama Al Madinah Brebes. Tujuan dari penelitian ini untuk menentukan gambaran dan persentase kejadian medication error pasien gastritis rawat inap di Klinik Pratama Al Madinah Brebes. Penelitian ini merupakan penelitian observasi deskriptif dengan menggunakan desain cross sectional pada pasien gastritis rawat inap. Pengambilan data dilakukan dengan mengumpulkan data pasien secara prospektif. Persentase Kejadian medication error pada pengobatan pasien gastritis rawat inap di Klinik Pratama Al Madinah adalah sebanyak 5 dari $27(18,52 \%)$ pasien yang mengalami medication error. Dari 5 pasien yang mengalami kejadian ME, 2 diantaranya disimpulkan mengalami ME terkait pemberian metoklopramide pada geriatri (kontraindikasi), 2 diantaranya lagi adalah terjadi kesalahan dalam pemberian sukralfat yang berbarengan dengan obat ranitidin, serta $1 \mathrm{ME}$ yang terjadi lagi adalah pemberian dexamethasone (golongan kortikosteroid) pada penderita gastritis

Kata Kunci :Medication error, Gastritis

1. Pendahuluan

Kesalahan pengobatan (medication error) adalah kejadian yang merugikan pasien akibat pemakaian obat selama dalam penanganan tenaga kesehatan, yang sebetulnya dapat dicegah (Kepmenkes, 2004). Kejadian medication error terjadi sebagai akibat dari kesalahan manusia atau lemahnya sistem yang ada. Besarnya kejadian medication error merupakan salah satu indikasi tingkat pencapai anpatient safety, khususnya terhadap tujuan tercapainya medikasi yang efektif dan aman. Salah satu faktor yang ikut menentukan ada tidaknya medication error adalah rasionalitas terapi. Penggunaan obat dikatakan rasional jika tepat secara medic dan memenuhi persyaratan persyaratan tertentu. Masing - masing persyaratan mempunyai konsekuensi yang berbeda - beda. Sebagai contoh, kekeliruan dalam menegakkan diagnosis akan member konsekuensi berupa kekeliruan dalam menentukan jenis pengobatan. Sedangkan menurut WHO (1985), penggunaan obat dikatakan rasional bila:

a. Pasien menerima obat yang sesuai dengan kebutuhannya.

b. Untuk periode waktu yang ade kuat.

c. Dengan harga yang paling murah untuknya dan masyarakat

Gastritis adalah suatu peradangan atau perdarahan pada mukosa lambung yang disebabkan oleh factor iritasi, infeksi, dan ketidak teraturan dalam pola makan, misalnya telat makan, makan terlalu banyak, cepat, makan makanan yang terlalu banyak bumbu dan pedas. Gastritis dapat dibagi menjadi akut dan kronik, piñata laksanaan medical untuk gastritis akut adalah dengan menghilangkan etiologinya, diet lambung dengan posisi kecil dan sering. Pencegahan dapat dilakukan dengan pemberian antasida dan antagonis $\mathrm{H} 2$ sehingga me ncapai $\mathrm{pH}$ lambung 4. Meskipun hasilnya masih jadi perdebatan, tetapi pada umumnya tetap dianjurkan. Pencegahan dapat dilakukan dengan pemberian antasida dan antagonis $\mathrm{H} 2$ sehingga mencapai $\mathrm{pH}$ lambung 4. Meskipun hasilnya masih jadi perdebatan, tetapi pada umumnya tetap dianjurkan. Sedangkan Penatalaksanaan untuk gastritis kronis adalah ditandai oleh progesifepitel kelenjar disertai sel parietal dan chief cell. Gastritis kronis diatasi dengan memodifikasi diet dan
\end{abstract}


meningkatkan istirahat, mengurangi dan memulai farmakoterapi. Helicobacter Pylory dapat diatasi dengan antibiotic (seperti Tetrasiklin atau Amoxicillin) dan garam bismut (Peptobismol). Pasien dengan gastritis tipe A biasanya mengalami malabsorbsi vitamin B12 (Chandrasoma, 2005 : 522).

\section{MetodePenelitian}

Penelitian ini merupakan penelitian observasi deskriptif dengan menggunakan desain cross sectional pada pasien gastritis rawat inap di Klinik Pratama Al Madinah Brebes. Pengumpulan data dilakukan secara prospektif dengan mengambil data pasien gastritis rawat inap di Klinik Pratama $\mathrm{Al}$ Madinah Brebes. Jenis data yang digunakan dalam penelitian ini adalah data primer dan data sekunder. Data primer diperoleh melalui Interview kepada pasien atau keluarga pasien dilakukan untuk menggali informasi yang diperlukan seperti riwayat penyakit dan pola hidup, riwayat pengobatan, keluhan dan kepatuhan pasien dalam meminum obat (jika ada obat yang diminum). Peneliti juga melakukan observasi untuk manifestasi klinis yang muncul terkait ada tidaknya harm pada pasien apabila terjadi medication error. Data sekunder diperoleh dari data rekam medis pasien mulai dari pasien masuk menjalani perawatan hingga keluar dari Klinik.

Data yang diperoleh kemudian dituliskan dalam form pengambilan data atauCase Record Form (CRF) yang sudahdibuatolehpeneliti.

1. Tahap Pengolahan Data

Teknik analisis data dilakukan dengan tahapan:

2. Reduksi Data:

Dengan menggolongkan, mengarahkan, membuang data yang tidak perlu dan mengorganisasikan data sedemikan rupa sehinggadapatditarikkesimpulanakhir.

a. Penyajian Data: Penyajian data digunakan untuk menemukan pola - pola yang bermakna disusun secara sistematis serta memberikan kemungkinan adanya penarikan kesimpulan. Data - data tersebut berwujud angka, kata - kata, kalimat, atau paragraf, oleh karena itu data akan disajikan dalam bentuk teks atau uraian naratif.

b. Penarikan Kesimpulan: Penentuan terjadi tidaknya medication error pada penelitian ini dilakukan dengan cara menilai kesesuaian atau ketepatan terapi obat yang diberikan pada pengobatan pasien gastritis dengan guide linenya. Hasil analisis data digunakan untuk menarik kesimpulan final sehingga dapat menggambarkan suatu peristiwa atau angka kejadian dan berusaha memberikan rekomendasi.

\section{Hasil dan Pembahasan}

Pengambilan sampel dalam penelitian ini merupakan total sampling,dimana seluruh pasien rawat inap gastritis yang berobat di Klinik Pratama Al-Madinah pada periode penelitian dan masuk dalam kriteria inklusi seluruhnya dimasukkan kedalam sampel penelitian. Selama periode penelitin, peneliti mendapatkan sampel sebanyak 27 pasien rawat inap gastritis. Dari 27 pasien tersebut lalu dilakukan pengambilan data, dimana pengambilan data dilakukan secara prospektif. Jenis data yang digunakan dalam penelitian ini adalah data primer dan data sekunder.Langkah selanjutnya setelah melakukan pengumpulan data pada pasien yang dijadikan sampel, selanjutnya adalah untuk mengkaji data-data pasien yang sudah terkumpul agar dapat ditarik sebuah kesimpulan, apakah pengobatan gastritis yang diterima pasien rawat inap telah sesuai atau tidak. Penentuan terjadi tidaknya medication error pada penelitian ini dilakukan dengan cara menilai kesesuaian atau ketepatan terapi obat yang diberikan pada pengobatan pasien gastritis dengan literatur - literatur yang sudah ada. Hasil analisis data digunakan untuk menarik kesimpulan akhir sehingga dapat menggambarkan suatu peristiwa atau angka kejadian medication error yang terjadi pada pengobatan gastritis, khususnya pasien rawat inap di Klinik Pratama Al Madinah Brebes.

Hasil kajian kejadian medication error terhadap sampel pasien gastritis rawat inap 
dalam penelitian ini adalah sebagai berikut : Selama periode penelitian (Mei-Juni 2017) di klinik Pratama Al Madinah, peneliti mendapat sampel sebanyak 27 pasien. Dari total 27 pasien yang bisa dijadikan sampel, dinyatakan bahwa sebanyak $22(81,48 \%)$ pasien tidak mengalami medication error, dan sebanyak 5 $(18,52 \%)$ pasien mengalami kejadian medication error dalam proses pengobatan gastritis nya.

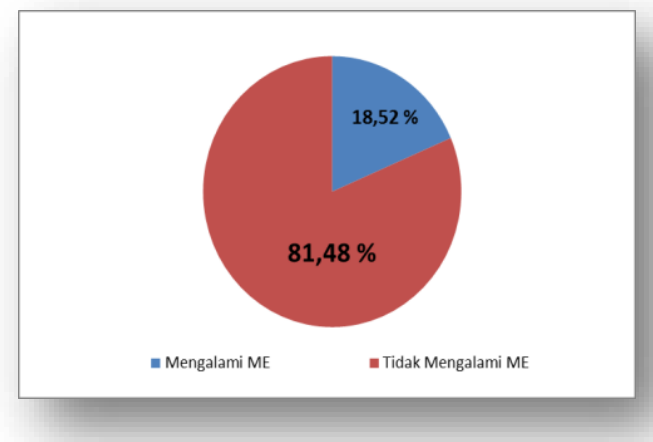

Gambar 1.

Dari lima pasien yang mengalami kejadian medication error, dua diantaranya disimpulkan mengalami medication error terkait pemberian metoklorpramide pada geriatri (kontraindikasi). Dua diantaranya lagi adalah terjadi kesalahan dalam pemberian sukralfat yang berbarengan dengan obat ranitidine. Satu medication error yang terjadi lagi adalah pemberian dexamethasone (golongan kortikosteroid) pada penderita gastritis.

Pada penelitian ini terjadi lima kejadian medication error dimana tiga medication error terjadi pada fase prescribing, dan dua medication error lagi terjadi pada fase administration.

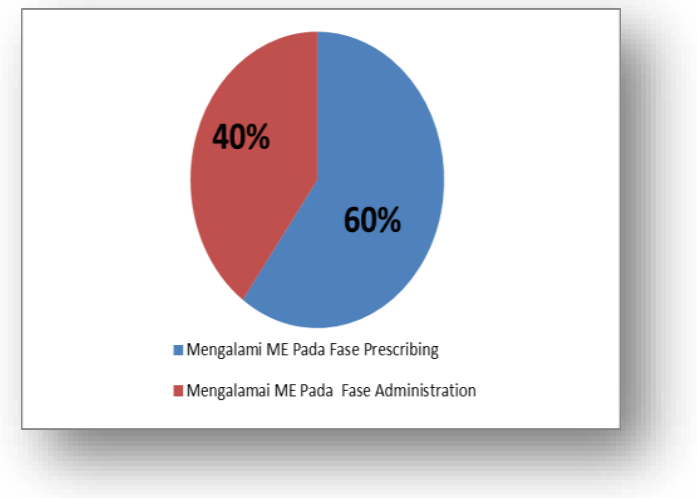

\section{Gambar 2}

Keterangan :

Fase prescribing, dimana error terjadi pada fase penulisan resep. Fase ini meliputi: obat yang diresepkan tidak tepat indikasi, tidak tepat pasien atau kontraindikasi $\rightarrow$ Total 3 Pasien Fase administration adalah error yang terjadi pada proses penggunaan obat. Fase ini dapat melibatkan petugas kesehatan, pasien atau keluarganya $\rightarrow$ Total 2 pasien

\section{Kesimpulan}

Hasil penelitian menunjukan Persentase Kejadian medication error pada pengobatan pasien gastritis rawat inap di Klinik Pratama Al Madinah adalahs ebanyak 5 dari 27 $(18,52 \%)$ pasien yang mengalami medication error. Dari 5 pasien yang mengalami kejadian ME, 2 diantaranya disimpulkan mengalami ME terkait pemberian metoklopramide pada geriatri (kontraindikasi), 2 diantaranya lagi adalah terjadi kesalahan dalam pemberian sukralfat yang berbarengan dengan obat ranitidin, serta 1 ME yang terjadi lagi adalah pemberian dexamethasone (golongan kortikosteroid) pada penderita gastritis.

Untuk tenaga kesehatan, perlu mengevaluasi kondisi pasien secara menyeluruh dan mengkaji obat - obat yang digunakan pada pasien terkait efektifitas dan ketepatan obat yang diberikan. Peneltian ini diharapkan dapat menjadi penelitian awal untuk melanjutkan penelitian medication error pada kasus gastritis ataupun penyakit lain di institusi pelayanan kesehatan lain yang lebih besar dengan jumlah pasien yang lebih 
banyak, sehingga dapat memperkaya data yang sudah ada.

\section{DaftarPustaka}

[1] Anonimous,2010. Gastritis. http://bluebe ar.student.umm.ac.id/2010/07/14/gastritis -magh. Diakses tanggal 14 Februari 2017.

[2] Arifianto. 2009. Gastritis. http://tonyarf87.blogdpot .com/2009/02/gastritis.htm. Diakses tanggal 04 Januari 2012, 09:05 WIB.

[3] Budiana. 2006. Gambaran Pengetahuan Klien Tentang Gastritis. http://www.scribd.com/doc/415 20350/Gambaran-Pengetahuan-KlienTentang-Gastritis/. Diakses tanggal 14 Februari 2017.

[4] Chandrasoma, Parakrama. 2005. Ringkasan Patologi Anatomi Edisi 2. Jakarta: EGC.

[5] Colin - Jones,D.G. Bloom, B. Bodemar, G. Grean., G. Freston, J. Gugler. R. Malagelada. 1988. Management of Dypepsia Report of a Working Party. Lancet.

[6] Ester,Monica.2001. PedomanPerawatanP asien. Jakarta: EGC.

[7] Friscaan. 2010. Semua Tentang Maag. http://www.medicalera.com/index .php ?option=com myblog. Diakses tanggal 14 Februari 2017.

[8] Ganong, William F. 2001. Buku Ajar Fisiologi Kedokteran. Jakarta: EGC.

[9] Guyton, Arthur C., John E. Hall. 2001. Buku Ajar Fisiologi Kedokteran. Jakarta: EGC.

[10] Iskandar, H. Yul. 2009. Saluran Cerna. Jakarta: Gramedia

[11] Kelly, Gregory. 2010. Perceived Stress Scale. http://healthsceneinvestigation.co m/files/2010/07/PercivedStressScale.pdf. Diakses tanggal 14 Februari 2017.

[12] Noto atmodjo,S oekidjo. 2005. Metodologi Penelitiaan Kesehatan. Jakarta: PT. AsdiMahasatya.

[13] Prince, Sylvia A., Lorraine McCarty Wilson. 2005. Patofisiologi
:KonsepKlinis Proses - Proses Penyakit. Jakarta: EGC.

[14] Soil, A.H. 1992. Gastritis. In: Cecil Texbook of Medicine $19^{\text {th }}$ edition. ed by Wynga arden, J.B., Smith, L.H., Bennet, J.C., W.B. Saunders Co., Philadelphia, pp.648-652.

[15] Suyono, Slamet. 2001. Buku Ajar Ilmu Penyakit Dalam. Jakarta: Balai Penerbitan FKUI. 